\title{
Performance of Holstein heifers fed sugarcane silages treated with urea, sodium benzoate or Lactobacillus buchneri
}

\author{
André de Faria Pedroso(1), Luiz Gustavo Nussio(2), Waldomiro Barioni Júnior ${ }^{(1)}$, Armando de Andrade Rodrigues(1), \\ Daniele Rebouças Santana Loures ${ }^{(2)}$, Fabio de Campos $^{(2)}$, José Leonardo Ribeiro(2), Lucas José Mari(2), \\ Maity Zopollatto(2), Marta Junqueira ${ }^{(2)}$, Patrick Schmidt(2), Solidete de Fátima Paziani(2) and Jorge Horii( ${ }^{(3)}$
}

(1)Embrapa Pecuária Sudeste, Caixa Postal 339, CEP 13560-970 São Carlos, SP, Brazil. E-mail: andref@cppse.embrapa.br (2)Universidade de São Paulo (USP), Escola Superior de Agricultura Luiz de Queiroz (Esalq), Dep. de Zootecnia, Caixa Postal 9, CEP 13418-900 Piracicaba, SP, Brazil. (3)USP, Esalq, Dep. de Agroindústria, Alimentos e Nutrição. E-mail: jhorii@carpa.ciagri.usp.br

\begin{abstract}
The objective of this work was to evaluate the performance of heifers fed sugarcane silages produced with and without additives. Thirty-two Holstein heifers were randomly assigned, in a block design, to evaluate rations (46\% silage; $54 \%$ concentrate; $12 \%$ crude protein) containing silages treated with (fresh basis) urea (0.5\%), sodium benzoate $(0.1 \%)$ or Lactobacillus buchneri $\left(3.64 \times 10^{5} \mathrm{cfu} \mathrm{g}^{-1}\right)$. Inoculation with L. buchneri improved daily gain ( $\left.1.24 \mathrm{vs.} 0.94 \mathrm{~kg} \mathrm{day}^{-1}\right)$, and the addition of benzoate resulted in better feed conversion (7.6 vs. $9.4 \mathrm{~kg}$ of dry matter per kg of live weight), in relation to the untreated silage (control). Treatments did not affect dry matter intake (mean of $2.19 \%$ of live weight). Rations containing silages treated with benzoate or L. buchneri showed lower cost per kg of weight gain. Treatment with urea did not improve animal performance, but the cost per kg of weight gain was lower than that of the control ration.
\end{abstract}

Index terms: additive, inoculant, nutritional value, weight gain.

\section{Desempenho de novilhas Holandesas alimentadas com silagens de cana-de-açúcar tratadas com uréia, benzoato de sódio ou Lactobacillus buchneri}

\begin{abstract}
Resumo - O objetivo deste trabalho foi avaliar a performance de novilhas alimentadas com silagens de cana-deaçúcar tratadas com aditivos. Trinta e duas novilhas Holandesas foram aleatoriamente distribuídas em um delineamento em blocos, para avaliar rações (46\% silagem; $54 \%$ concentrado; $12 \%$ proteína bruta) contendo silagem tratada com (base matéria verde) uréia $(0,5 \%)$, benzoato de sódio $(0,1 \%)$ ou Lactobacillus buchneri $\left(3,64 \times 10^{5}\right.$ ufc $\left.^{-1}\right)$. A inoculação de $L$. buchneri melhorou o ganho diário (1,24 vs. 0,94 $\left.\mathrm{kg} \mathrm{dia}^{-1}\right)$ e a adição de benzoato melhorou a conversão alimentar (7,6 vs. 9,4 kg de matéria seca por kg de peso vivo), relativamente ao controle (silagem não tratada). Os tratamentos não afetaram o consumo de matéria seca (2,19\% do peso vivo). As rações com silagens tratadas com benzoato ou $L$. buchneri mostraram menor custo por kg de ganho de peso. O tratamento com uréia não melhorou o desempenho animal, mas o custo por kg de ganho de peso foi menor do que na dieta controle.
\end{abstract}

Termos para indexação: aditivo, inoculante, valor nutritivo, ganho de peso.

\section{Introduction}

Ensiling of sugarcane may contribute to better feeding and field management, and prevents total loss of the forage in the occurrence of fires and frosts. However, fermentation in sugarcane silage is normally dominated by yeasts, which metabolise sugars to ethanol, carbonic gas and water, resulting in excessive dry matter (DM) losses and low quality forages (Alli et al., 1982; Kung
Junior \& Stanley, 1982). Controlling yeasts is, therefore, essential for the successful ensilage of sugarcane.

Several products have been tested as additives to sugarcane silages, to control yeast development and reduce losses of DM. Urea breaks down to ammonia in the silo, and has a toxic effect on yeasts and moulds. This effect was observed by Alli et al. (1983), who reported reduction in yeast counts, ethanol production and DM losses, and lower disappearance of water-soluble 
carbohydrates (WSC) in sugarcane silage treated with ammonia. Pedroso (2003) reported lower fiber, increased protein content, decreased DM losses and improved in vitro dry matter digestibility (IVDMD) of sugarcane silage treated with 5 to $15 \mathrm{~g}$ of urea $\mathrm{kg}^{-1}$ of fresh forage, but without reduction in the ethanol concentration in the silage.

Benzoic acid has fungicidal properties (Woolford, 1975) and sodium benzoate reduces yeast counts, improving conservation and aerobic stability of grass silages (Lättemäe \& Lingvall, 1996). Pedroso (2003) observed that treatment with sodium benzoate at concentrations varying from 0.5 to $2 \mathrm{~g} \mathrm{~kg}^{-1}$ increased IVDMD and aerobic stability, but did not reduce ethanol content in the silages.

Yeast populations can also be controlled by bacterial inoculants. The heterofermentative bacteria Lactobacillus buchneri converts lactic acid to acetic acid, 1,2 propanediol, propionic acid, $\mathrm{CO}_{2}$ and traces of ethanol (Oude Elferink et al., 2001); acetic acid has a relatively high fungicidal effect. Inoculation with L. buchneri reduced yeast counts and improved aerobic stability in corn and high moisture corn silages (Ranjit \& Kung Junior, 2000; Taylor et al., 2002). In sugarcane silages, inoculation with this bacteria reduced ethanol concentration and decreased DM loss (Pedroso, 2003).

The beneficial effects of additives over the chemical composition of sugarcane silages may result in silages with better nutritional value.

The objective of this experiment was to evaluate the performance of growing heifers fed rations containing untreated sugarcane silage or silages treated with additives.

\section{Material and Methods}

The experiment was conducted at the Department of Animal Science of Esalq, Universidade de São Paulo (Piracicaba, SP, Brazil). The experimental silages were produced with sugarcane, variety RB78-5841 (Ufscar, Araras, SP, Brazil), approximately 12 months old, burnt at field, and ensiled in $12 \mathrm{t}$ pit silos in three subsequent days. The forage was mechanically harvested with a Menta harvester adjusted for a theoretical cut length between 5 and $10 \mathrm{~mm}$.

Four types of silages were produced: silage without additives and silages treated with urea (granulated fertilizer, 45\% N), sodium benzoate (soluble granulated form) or an inoculant containing Lactobacillus buchneri (strain NCIMB 40788). Ensiling was initiated simultaneously for all treatments, but logistic problems caused slower filling of some silos. Sealing occurred 36 hours after the forage burning for the control silage; 60 hours after for the urea treated silage; and 84 hours after for silages treated with benzoate and $L$. buchneri.

Sodium benzoate and the bacterial inoculant, as aqueous solutions, were applied through manual sprayers to the chopped sugarcane, while it was loaded manually into the silos. Sodium benzoate was applied using $13 \mathrm{~L}$ of solution $\mathrm{t}^{-1}$, aiming $0.1 \%$ in the silage (fresh basis) and the bacterial inoculant to obtain $3.64 \times 10^{5} \mathrm{cfu} \mathrm{g}^{-1}$ (fresh basis), using $1.89 \mathrm{~L}$ of solution $\mathrm{t}^{-1}$. Urea was applied in its dry form, in order to achieve $0.5 \%$ in the silage (fresh basis). Additives were dosed based on the volume of forage $\left(300 \mathrm{~kg} \mathrm{~m}^{-3}\right)$ contained in each wagon. Forage density was calculated using data from previously weighed wagons.

Silos were opened after 96 days of storage. Considering the presence or not of urea in the silage, two basic rations were formulated (Table 1) to contain $12 \%$ of crude protein (CP), $70 \%$ total digestible nutrients (TDN), 2.50 Mcal kg-1 metabolizable energy, according to the National Research Council (2001), aiming daily weight gains of $0.850 \mathrm{~kg} \mathrm{~d}^{-1}$ for growing Holstein heifers weighing $450 \mathrm{~kg}$. Rations were formulated intending to explore the high potential of weight gain of Holstein cattle. Composition of feeds used for formulating rations (Table 1) are average values from previous analysis carried out by the Laboratory of Bromatology of the Department of Animal Science (Esalq).

Table 1. Chemical composition and percentage of feeds in experimental $\operatorname{diets}^{(1)}$.

\begin{tabular}{lcrcccc}
\hline Ingredient & TDN & \multicolumn{1}{c}{ CP } & ME & \multicolumn{2}{c}{ Treatment (\% in DM) } \\
\cline { 6 - 7 } & $---(\%$ DM) & --- & $\left(\mathrm{Mcal} \mathrm{kg}^{-1}\right)$ & Without urea $^{(2)}$ & With urea $^{(3)}$ \\
\hline Sugarcane silage & 53 & 2 & 2.17 & 45.90 & 46.20 \\
Ground pearl millet seeds & 82 & 15 & 2.96 & 35.70 & 35.90 \\
Citrus pulp (pellets) & 82 & 7 & 2.96 & 15.00 & 15.10 \\
Urea & - & 271 & - & 1.55 & 0.92 \\
Mineral supplement & - & - & - & 1.84 & 1.85 \\
\hline
\end{tabular}

${ }^{(1)} \mathrm{TDN}$ : total digestible nutrients; CP: crude protein; ME: metabolizable energy; DM: dry matter. ${ }^{(2)}$ Rations containing sugarcane silages produced without urea: untreated silage (control), and silages treated with $0.1 \%$ sodium benzoate or Lactobacillus buchneri at the rate of $3.64 \times 10^{5} \mathrm{cfu} \mathrm{g}^{-1}$. ${ }^{(3)}$ Ration containing sugarcane silage produced with $0.5 \%$ urea. 
Thirty two Holstein heifers (7.5 to 24 months old) were distributed in four blocks, according to age and weight, and randomly assigned to one of the four treatments: ration containing untreated sugarcane silage (control), or rations containing sugarcane silages treated with urea (UREA), benzoate (BENZ) or inoculated with L. buchneri (BUCH). The mean initial weight in the blocks were 495, 448, 391 and $220 \mathrm{~kg}$. Heifers were housed in $33 \mathrm{~m}^{2}$ (3x11 m) covered pens with concrete floor. Two animals were assigned to each pen, in order to achieve the smallest weight variation across pens, within each block.

Animals were fed once a day, approximately at $18 \mathrm{~h}$. The silage and the concentrate, referring to each pen, were weighed separately in an electronic scale, sacked for transport and mixed manually in the bunks. Refusals were quantified daily for adjustment of next day feeding, to allow ad libitum consumption of rations (10\% refusals).

Refusals and silages were sampled once a week for chemical analysis. Samples for WSC, $\mathrm{pH}$ and ethanol determinations were kept frozen $\left(-10^{\circ} \mathrm{C}\right)$ until analysis. Other samples were dried in air forced dry oven $\left(60^{\circ} \mathrm{C}\right.$, 48 hours) and grounded in a Wiley mill through a $1 \mathrm{~mm}$ screen. Dry chemistry analysis was performed by Near Infrared Spectroscopy (NIRS) (Berzaghi et al., 1997), in a spectrophotometer model NIRS 5000. The equipment software indicated approximately $30 \%$ of the samples that had to be analysed by wet chemistry, for subsequent inference of the composition of all samples. Wet chemical analysis followed the recommendations of the Association of Official Analytical Chemists (1990) for DM, ash and CP. Acid detergent fiber (ADF) and neutral detergent fiber (NDF) were expressed exclusive of ash. Lignin was determined by solubilization of cellulose with sulphuric acid. NDF was assayed with sodium sulphite and without alpha amylase, according to Van Soest \& Robertson (1985). IVDMD was estimated in a Daisy incubator. Ethanol, WSC and pH were determined in aqueous extracts produced according to the method described by Kung Junior et al. (1984). WSC were determined by the phenol sulphuric acid method (DuBois et al., 1956). Ethanol was analysed in a HP 5890 Series II gas chromatograph, equipped with a flame ionisation detector, a $2 \mathrm{~m}$ x $2 \mathrm{~mm}$ ID column packed with chromosorb 101 (Johns Manville, Denver, USA), and an electronic integrator. The DM concentration of the silages, determined every weak, was used to adjust the amount of silage in each ration.

Animals were weighed in days 0,30 and 60, after 12 hours of fasting (solid feed), for analysis of live weigth (LW) gain.

Data relative to animal performance were analysed using the GLM procedure of SAS (SAS Institute, 2001), for a completely randomized block design (4 blocks with 4 treatments each). The experimental unit considered was the mean of pen containing two animals each. The ANOVA model considered effects of blocks and treatments. Treatments were compared by contrast using Student's t test.

In the economic analysis, it was considered the regional market price for the feeds (November 2005). To calculate the gross income, the price paid to farmers ( $\mathrm{R} \$ \mathrm{~kg}^{-1}$ of dairy heifers LW) was considered to be $100 \%$ above the price paid for beef cattle (Miranda et al., 1999; Anualpec, 2005).

\section{Results and Discussion}

Chemical composition of the freshly chopped burned sugarcane and experimental silages can be found in Table 2 . The quality of the sugarcane can be considered as normal for a modern Brazilian variety of sugarcane (Rodrigues et al., 1997). Silages with or without additives differed little with respect to parameters considered in the laboratory analysis. The only differences detected were the higher DM content of the sugarcane silage treated with sodium benzoate, in relation to silage without additive; the higher CP content in the silage treated with urea, indicating good recovery of the nitrogen applied

Table 2. Chemical composition (mean \pm SE) of the fresh sugarcane and of the experimental silages.

\begin{tabular}{|c|c|c|c|c|c|c|c|c|}
\hline \multirow[t]{2}{*}{ Parameter $^{(1)}$} & \multirow[t]{2}{*}{ Sugarcane $^{(2)}$} & \multicolumn{7}{|c|}{ Silage $^{(3)}$} \\
\hline & & Con & trol & Ure & & Benz & oate & L. buchneri \\
\hline DM & 31.91 & 30.06 & 2.20 & 31.30 & 3.59 & 35.36 & 0.80 & $34.11 \quad 1.58$ \\
\hline pH & 5.38 & 3.82 & 0.09 & 3.89 & 0.09 & 3.81 & 0.12 & 3.830 .06 \\
\hline WSC & 26.42 & 15.38 & 2.91 & 16.57 & 1.85 & 16.32 & 0.24 & $\begin{array}{ll}15.93 & 0.37\end{array}$ \\
\hline Ash & 6.59 & 6.79 & 1.02 & 5.56 & 0.48 & 5.80 & 1.16 & 6.210 .87 \\
\hline $\mathrm{CP}$ & 3.37 & 2.89 & 1.00 & 6.37 & 1.68 & 2.62 & 0.49 & $\begin{array}{ll}1.96 & 0.25\end{array}$ \\
\hline NDF & 47.21 & 51.76 & 3.99 & 54.90 & 6.33 & 52.53 & 2.50 & $49.14 \quad 1.65$ \\
\hline $\mathrm{ADF}$ & 35.95 & 36.93 & 1.60 & 38.37 & 3.76 & 37.26 & 1.48 & $34.82 \quad 1.21$ \\
\hline LIG & 6.90 & 7.23 & 0.30 & 7.20 & 0.44 & 7.19 & 0.24 & $\begin{array}{ll}6.40 & 0.38\end{array}$ \\
\hline IVDMD & 55.31 & 52.34 & 2.58 & 51.81 & 3.99 & 52.15 & 1.88 & $55.22 \quad 1.20$ \\
\hline Ethanol & 0.21 & 0.44 & 0.38 & 0.89 & 0.79 & 0.30 & 0.08 & $\begin{array}{ll}0.29 & 0.08\end{array}$ \\
\hline
\end{tabular}

${ }^{(1)} \mathrm{DM}$ : dry matter; WSC: water soluble carbohydrates; CP: crude protein; NDF: neutral detergent fiber; ADF: acid detergent fiber; LIG: lignin; IVDMD: in vitro DM digestibility. ${ }^{(2)}$ Freshly chopped burnt sugarcane. (3)Untreated sugarcane silage (control), and sugarcane silages treated with (fresh basis) $0.5 \%$ urea, $0.1 \%$ sodium benzoate or Lactobacillus buchneri at the rate of $3.64 \times 10^{5} \mathrm{cfu} \mathrm{g}^{-1}$. 
through the additive; and the lower lignin content in the silage treated with $L$. buchneri relative to the other silages. Ethanol concentrations in the silages were atypically low. Data from the literature indicate ethanol contents ranging from 3.1 to $15.5 \%$ (DM basis), for sugarcane silages produced without additives, and a minimum of $1.8 \%$ for L. buchneri inoculated silage (Preston et al., 1976; Kung Junior \& Stanley, 1982; Pedroso, 2003). There was probably extensive volatilisation of the alcohol, since only $10 \mathrm{~cm}$ layers of silage were taken daily from each silo, to attend demand from animals.

There was no difference in DM intake of rations between treatments (Table 3). This result differs from those obtained by Silvestre et al. (1976), who reported a greater intake of sugarcane silage treated with additive compared to untreated one. The mean DM intake corresponded to $2.2 \%$ of LW (Table 3). This intake is higher than the value of 1.6 or $1.7 \%$ of LW for diets with sugarcane silage observed by Silvestre et al. (1976) and Alvarez et al. (1977), although these authors supplemented each animal with only $0.5 \mathrm{~kg} \mathrm{~d}^{-1}$ of groundnut cake or rice polishing, respectively. There are very few scientific papers published evaluating intake and performance of cattle fed sugarcane silage.

Heifers daily LW gain was higher than predicted (Table 3), varying from 0.94 to $1.24 \mathrm{~kg} \mathrm{~d}^{-1}$. Using the IVDMD as the approximate value of TDN of silages, considering DM intake of rations and composition of silages and concentrates (Tables 1 and 2), the mean intake of CP calculated was $1.07 \mathrm{~kg}_{\text {animal }}{ }^{-1} \mathrm{~d}^{-1}$, which is enough for heifers to gain more weight than predicted by the National Research Council (2001), but the mean intake of TDN (6.2 kg animal-1 $\left.\mathrm{d}^{-1}\right)$ would limit LW gain to $0.8 \mathrm{~kg} \mathrm{~d}^{-1}$. It can be suggested that the IVDMD and, consequently, the TDN of silages were subestimated, since loss of volatile components, during oven drying, can reach up to $8.8 \%$ of correct DM (McDonald \& Dewar, 1960, cited by Porter \& Barton, 1997).

Animals fed the diet containing sugarcane silage inoculated with $L$. buchneri presented LW gain 31.9\% higher $(p<0.01)$ and better feed conversion $(p<0.054)$, in relation to animals fed diet with sugarcane silage without additive, consuming $17.5 \%$ less DM for each $\mathrm{kg}$ of LW gain. Feed conversion (7.73 kg of DM kg-1 of LW gain) of animals fed the inoculated silage was much better than the value of $12.4 \mathrm{~kg}$ of DM, for each $\mathrm{kg}$ of LW gain reported by Valvasori et al. (1998), for animals fed diets containing approximately $60 \%$ sugarcane silage plus cotton seed meal. The greater intake of TDN may explain the greater LW gain obtained in this treatment in relation to animals fed diet containing sugarcane silage without additive. The lowest lignin content observed in the silage inoculated with $L$. buchneri might have contributed to higher gain in this treatment.

Animals fed the diet containing silage treated with sodium benzoate had higher LW gain $(\mathrm{p}<0.058)$ and better feed conversion ( $\mathrm{p}<0.05$ ), consuming $18.6 \%$ less DM for each kg of LW gain, in relation to animals fed diet with sugarcane silage without additive. In general, sugarcane silages treated with benzoate and $L$. buchneri allowed similar animal performance. Although sugarcane silage treated with urea had higher crude protein, it did not improve animal performance in comparison to sugarcane silage without additive. This may have occurred because part of nitrogen reacts with lignin, and becomes indigestible (Van Soest, 1994).

Feed costs of rations containing sugarcane silages treated with sodium benzoate or $L$. buchneri were higher than costs for diets with sugarcane silage without additive, however, those rations resulted in higher gross income (Table 4) and higher gross margin. Urea

Table 3. Performance of Holstein heifers fed diets containing sugarcane silages.

\begin{tabular}{|c|c|c|c|c|c|c|}
\hline Treatment $^{(1)}$ & Initial weight & Final weight & Daily gain & $\begin{array}{l}\text { Dry matter } \\
\text { consumption } \\
\left(\mathrm{kg} \mathrm{d}^{-1}\right) \\
\end{array}$ & $\begin{array}{l}\text { Dry matter consumption } \\
\qquad(\% \text { LW }) \\
\end{array}$ & $\begin{array}{c}\text { Feed } \\
\text { conversion } \\
\left(\mathrm{kg} \mathrm{DM} \mathrm{kg}^{-1} \mathrm{LWg}\right)^{(2)}\end{array}$ \\
\hline Control & 387.3 & 443.5 & 0.94 & 8.72 & 2.15 & 9.37 \\
\hline Urea & 392.3 & 453.8 & 1.03 & 8.75 & 2.17 & 8.63 \\
\hline BENZ & 400.3 & 468.5 & 1.14 & 8.61 & 2.12 & 7.63 \\
\hline $\mathrm{BUCH}$ & 391.4 & 465.8 & 1.24 & 9.61 & 2.35 & 7.73 \\
\hline & \multicolumn{6}{|c|}{ Contrasts $(\operatorname{Pr}>|t|)$} \\
\hline Control x urea & 0.5680 & 0.2461 & 0.3750 & 0.9590 & 0.9165 & 0.3446 \\
\hline Control x BENZ & 0.1577 & 0.0143 & 0.0582 & 0.8606 & 0.7763 & 0.0444 \\
\hline Control x BUCH & 0.6366 & 0.0247 & 0.0093 & 0.1501 & 0.2601 & 0.0544 \\
\hline BENZ x BUCH & 0.3203 & 0.7469 & 0.2894 & 0.1133 & 0.1692 & 0.9038 \\
\hline
\end{tabular}

(1) Rations containing approximately 54\% concentrate, and 46\% untreated sugarcane silage (control) or sugarcane silages treated with (fresh basis) $0.5 \%$ urea, $0.1 \%$ sodium benzoate (BENZ) or L. buchneri at the rate of $3.64 \times 10^{5} \mathrm{cfu} \mathrm{g}^{-1}$ (BUCH). ${ }^{(2)} \mathrm{LWg}$ : live weight gain. 
Table 4. Economics of growing Holstein heifers fed rations containing untreated sugarcane silage and silages treated with additives.

\begin{tabular}{|c|c|c|c|c|}
\hline \multirow[t]{2}{*}{ Parameter per animal } & \multicolumn{4}{|c|}{ Treatment $^{(1)}$} \\
\hline & Control & Urea & BENZ & $\overline{\mathrm{BUCH}}$ \\
\hline Total fed ration $\left(\mathrm{kg} \mathrm{DM} \mathrm{d}^{-1}\right)^{(2)}$ & 9.59 & 9.63 & 9.47 & 10.57 \\
\hline Ration cost $\left({\left.\mathrm{R} \$ \mathrm{~kg}^{-1} \mathrm{DM}\right)}^{-1}\right.$ & 0.18 & 0.18 & 0.19 & 0.19 \\
\hline Feed cost $\left(R S d^{-1}\right)$ & 1.73 & 1.73 & 1.80 & 2.01 \\
\hline Weight gain $\left(\mathrm{kg} \mathrm{d}^{-1}\right)$ & 0.94 & 1.03 & 1.14 & 1.24 \\
\hline Price paid to the farmers $\left(\mathrm{R} \$ \mathrm{~kg}^{-1}\right)$ & 3.53 & 3.53 & 3.53 & 3.53 \\
\hline Gross income $\left(\mathrm{RS} \mathrm{d}^{-1}\right)$ & 3.32 & 3.64 & 4.02 & 4.38 \\
\hline Gross margin $\left(\mathrm{RS} \mathrm{d}^{-1}\right)$ & 1.59 & 1.91 & 2.22 & 2.37 \\
\hline Cost kg ${ }^{-1}$ weight gain & 1.84 & 1.67 & 1.57 & 1.62 \\
\hline
\end{tabular}

${ }^{(1)}$ Rations containing approximately $54 \%$ concentrate and $46 \%$ untreated sugarcane silage (control) or silages containing $0.5 \%$ urea (UREA), $0.1 \%$ sodium benzoate (BENZ) or L. buchneri at the rate of $3.64 \times 10^{5} \mathrm{cfu} \mathrm{g}^{-1}$ (BUCH). ${ }^{(2)}$ Dry matter consumed plus $10 \%$ surplus per animal per day.

treatment resulted in intermediary gross margin. Rations containing sugarcane silages treated with sodium benzoate or $L$. buchneri were economically viable, showing lower cost per kg of weight gain and higher gross margin than other rations.

\section{Conclusions}

1. Rations containing sugarcane silages treated with sodium benzoate or L. buchneri improve weight gain and feed conversion with lower cost per kg of weight gain.

2. The cost per kg of weight gain is lower for rations containing silage treated with urea than for rations with untreated sugarcane silage.

\section{References}

ALLI, I.; BAKER, B.E.; GARCIA, G. Studies on the fermentation of chopped sugarcane. Animal Feed Science and Technology, v.7, p.411-417, 1982.

ALLI, I.; FAIRBAIRN, R.; BAKER, B.E.; GARCIA, G. The effects of ammonia on the fermentation of chopped sugarcane. Animal Feed Science and Technology, v.9, p.291-299, 1983.

ALVAREZ, F.J.; PRIEGO, A.; PRESTON, T.R. Animal performance on ensiled sugar cane. Tropical Animal Production, v.2, p.27-33, 1977.

ANUALPEC 2005. São Paulo: FNP, 2005. 340p.

ASSOCIATION OF OFFICIAL ANALYTICAL CHEMISTS (Arlington, Estados Unidos). Official methods of analysis. $15^{\text {th }}$ ed. Arlington, 1990. 1117p.

BERZAGHI, P.; COZZI, G.; ANDRIGHETTO, I. The use of near infrared analysis for in situ studies. Journal of Dairy Science, v.80, p.3263-3270, 1997.

DuBOIS, M.; GILLES, K.A.; HAMILTON, J.K.; REBERS, P.A.; SMITH, F. Colorimetric method for determination of sugars and related substances. Analytical Chemistry, v.28, p.350-356, 1956.
KUNG JUNIOR, L.; GRIEVE, D.B.; THOMAS, J.W.; HUBER, J.T. Added ammonia or microbial inocula for fermentation and nitrogenous compounds of alfalfa ensiled at various percents of dry matter. Journal of Dairy Science, v.67, p.299-306, 1984.

KUNG JUNIOR, L.; STANLEY, R.W. Effect of stage of maturity on the nutritive value of whole-plant sugarcane preserved as silage. Journal of Animal Science, v.54, p.689-696, 1982.

LÄTTEMÄE, P.; LINGVALL, P. Effect of hexamine and sodium nitrite in combination with sodium benzoate and sodium propionate on fermentation and storage stability of wilted and long cut grass silage. Swedish Journal of Agricultural Research, v.26, p.135146, 1996.

MIRANDA, L.F.; QUEIROZ, A.C.; VALADARES FILHO, S.C.; CECON, P.R.; PEREIRA, E.S.; PAULINO, M.F.; CAMPOS, J.M.S.; MIRANDA, J.R. Desempenho e desenvolvimento ponderal de novilhas leiteiras alimentadas com dietas à base de cana-de-açúcar. Brazilian Journal of Animal Science, v.28, p.605-613, 1999.

NATIONAL RESEARCH COUNCIL (Washington, DC). Nutrient requirements of dairy cattle. $7^{\text {th }}$ ed. Washington: National Academy Press, 2001. 381p.

OUDE ELFERINK, S.J.W.H.; KROONEMAN, J.; GOTTSCHAL, J.C.; SPOELSTRA, S.F.; FABER, F.; DRIEHUIS, F. Anaerobic conversion of lactic acid to acetic acid and 1,2-propanediol by Lactobacillus buchneri. Applied and Environmental Microbiology, v.67, p.125-132, 2001.

PEDROSO, A. de F. Aditivos químicos e microbianos no controle de perdas e na qualidade de silagem de cana-de-açúcar (Saccharum officinarum L.). 2003. 120p. Tese (Doutorado) - Escola Superior de Agricultura Luiz de Queiroz, Piracicaba.

PORTER, M.G.; BARTON, D. A comparison of methods for the determination of dry matter concentration in grass silage including an extraction method for water. Animal Feed Science and Technology, v.68, p.67-76, 1997.

PRESTON, T.R.; HINOJOSA, C.P.; MARTINEZ, L. Ensiling of sugar cane with ammonia molasses and mineral acids. Tropical Animal Production, v.1, p.120-127, 1976.

RANJIT, N.K.; KUNG JUNIOR, L. The effect of Lactobacillus buchneri, Lactobacillus plantarum, or a chemical preservative on the fermentation and aerobic stability of corn silage. Journal of Dairy Science, v.83, p.526-535, 2000.

RODRIGUES, A. de A.; PRIMAVESI, O.; ESTEVES, S.N. Efeito da qualidade de variedades de cana-de-açúcar sobre seu valor como alimento para bovinos. Pesquisa Agropecuária Brasileira, v.32, p.1333-1338, 1997.

SAS INSTITUTE (Cary, Estados Unidos). System for Microsoft Windows. Release 8.2. Cary, NC, 2001. 1 CD-ROM.

SILVESTRE, R.; MacLEOD, N.A.; PRESTON, T.R. The performance of steers fed fresh chopped whole sugar cane or after ensiling with urea or ammonia. Tropical Animal Production, v.1, p.40, 1976. 
TAYLOR, C.C.; RANJIT, N.J.; MILLS, J.A.; NEYLON, J.M.; KUNG JUNIOR, L. The effect of treating whole-plant barley with Lactobacillus buchneri 40788 on silage fermentation, aerobic stability, and nutritive value for dairy cows. Journal of Dairy Science, v.85, p.1793-1800, 2002.

VALVASORI, E.; LUCCI, C. de S.; PIRES, F.L.; ARCARO, J.R.P.; ARCARO JUNIOR, I. Desempenho de bezerros recebendo silagens de sorgo ou cana-de-açúcar como únicos alimentos volumosos. Brazilian Journal of Veterinary Research and Animal Science, v.35, p.229-232, 1998.
VAN SOEST, P.J. Nutritional ecology of the ruminant. $2^{\text {nd }} \mathrm{ed}$. Ithaca: Cornell University Press, 1994. 476p.

VAN SOEST, P.J.; ROBERTSON, J.B. Analysis of forages and fibrous foods: a laboratory manual for animal science. Ithaca: Cornell University Press, 1985. 202p.

WOOLFORD, M.K. Microbiological screening of food preservatives, cold sterilants and specific antimicrobial agents as potential silage additives. Journal of the Science of Food and Agriculture, v.26, p.226-237, 1975.

Received on December 28, 2004 and accepted on December 5, 2005 